\title{
A vertical diffusion method for the microbiological assay of isoniazid
}

\author{
JANET LLOYD AND D. A. MITCHISON \\ From the Medical Research Council's Unit for Research on Drug Sensitivity \\ in Tuberculosis, Postgraduate Medical School of London
}

SYNPOSIS A method is described for the assay of isoniazid in serum and other fluids by diffusion along slopes of Löwenstein-Jensen medium inoculated with tubercle bacilli. The method is convenient, rapid and robust, but is less accurate than diffusion systems for the assay of some other substances.

Methods for the microbiological assay of isoniazid by diffusion along slopes of egg medium inoculated with $M$. tuberculosis have been described by Schmiedel $(1954,1958 \mathrm{a}$ and b) and by Grosset and Canetti $(1958,1960)$. Diffusion methods for the assay of isoniazid in serum are considered by several authors (Schmidt, 1962; Dufour, Knight, and Harris, 1963; Sunahara, Urano, Lin, Cheg, and Jarumilinda, 1963) to be more convenient and precise than dilution methods. We have used a diffusion method for the past four years. This method is described here, since it differs in certain respects from the previous methods and since a number of factors affecting the assay have been studied.

METHOD

TEST STRAIN A streptomycin-resistant variant of strain H37Rv was obtained by heavy inoculation on to Löwenstein-Jensen medium containing $1,024 \mu \mathrm{g} . / \mathrm{ml}$. streptomycin. Resistant colonies were subcultured into 7H-10 Tween-albumin liquid medium (Cohn, Middlebrook, and Russell, 1959) containing $100 \mu \mathrm{g}$. $/ \mathrm{ml}$. streptomycin and the strain was maintained by serial subcultivation on the same medium.

MEDIUM Löwcnstein-Jensen medium without potato starch (Jensen, 1955), containing $100 \mu \mathrm{g} . / \mathrm{ml}$. streptomycin, was distributed in $4 \mathrm{ml}$. volumes into $16 \times 150 \mathrm{~mm}$. test tubes which were closed with rubber bungs, pierced by cotton-wool-plugged, 17 gauge hypodermic needles to prevent the bungs blowing out during inspissation. The medium was inspissated for $50 \mathrm{~min}$. at $85^{\circ} \mathrm{C}$. with the tubes lying horizontally, so that a uniform layer of medium was obtained along the tubes. The tubes containing medium are referred to below as 'slopes'.

INOCULATION OF THE SLOPES The water of condensation was first removed from the slopes with a Pasteur pipette. Received for publication 16 March 1964.
Inoculation was then done with a long wire ending in a $z$ loop wrapped round a felt cylinder, $6 \mathrm{~mm}$. dia $\times 8 \mathrm{~mm}$., conveniently cut from the nib of a Flowmaster pen (Stuart Thompson Ltd., Wembley, Mdsx.) and sterilized by hot air. The cylinder was dipped in a 1:4 dilution of a 10-day culture of the test strain, drained free of surplus $\vec{\theta}$ liquid, and drawn once down and up the centre of the entire length of the Löwenstein-Jensen medium slope with the circular end of the cylinder flat on the surface of the medium.

MATERIAL TO BE ASSAYED The serum or other fluid to be assayed was warmed to $56^{\circ} \mathrm{C}$. and mixed with melted $4 \%$ aqueous agar (New Zealand agar, Davis Gelatine Ltd., Warwick) in the proportion of $1 \mathrm{ml}$. serum to $0.2 \mathrm{ml}$. agar. Control solutions containing known concentrations of isoniazid in water or serum were also mixed with agar. With a $1 \mathrm{ml}$. pipette, $0.5 \mathrm{ml}$. of the mixture was added to the base of a slope and allowed to set with the slope standing vertically; in this way a solid butt? was formed which did not slop over the surface of the slope during subsequent handling. In the work to be described at least three different control solutions were $\delta$ used in each experiment. However, since a linear relation- 3 ship was found between the length of the zone of inhi- 을 bition and the logarithm of the isoniazid concentration, it is not necessary to set up more than two control solu- $\frac{7}{0}$ tions in the routine assay of serum. These should be chosen at the lower and the upper limits of the concen- $N$ trations expected; concentrations of 0.1 and 6.4 $\mu \mathrm{g} . / \mathrm{ml}$. isoniazid would be suitable for most purposes. 0 A reasonable degree of accuracy may be obtained by $N$ setting up each of the sera to be assayed on three slopes $\sigma$ and each of the two control solutions on five slopes. Control solutions should theoretically be prepared in human serum, since, as will be shown, the concentrations \& in serum are assayed as $70-80 \%$ of those in water. However, for most purposes, the use of control solutions in water can be recommended on grounds of convenience.

INCUBATION AND READING The slopes were incubated $\overparen{D}$ at $37^{\circ} \mathrm{C}$. for periods ranging from 10 to 28 days, but a 
period of 10 days was found to be the most satisfactory. Their tubes were then marked with a grease pencil (1) at the junction of the serum-agar butt and the LöwensteinJensen medium and (2) at the upper end of the zone of inhibition of growth, ignoring small or isolated colonies which occasionally grew within the zone. The distance between these marks was then read with a ruler to the nearest millimetre. Since the upper end of the zone of inhibition was not easy to define precisely, it was considered advisable to avoid bias by measuring between the grease pencil marks rather than by reading directly to the edge of the zone with a ruler. Furthermore, the slopes were read in a random order to prevent previous readings of replicate tubes influencing the observer. The mean lengths of the zone of inhibition obtained with the controls were plotted on semi-logarithmic graph paper and joined by a straight line. (When more than two control solutions were used, the line was fitted by the method of least squares.) The isoniazid concentration in the test serum was then read from this line.

RANGE OF ASSAY Zones of inhibition could almost always be obtained when the fluid assayed contained $0.1 \mu \mathrm{g} . / \mathrm{ml}$. isoniazid and often when it contained 0.05 $\mu \mathrm{g} . / \mathrm{ml}$. isoniazid. With concentrations of $12 \cdot 8 \mu \mathrm{g} . / \mathrm{ml}$, an occasional slope in some assays yielded no growth at all, and with concentrations of $25.6 \mu \mathrm{g} . / \mathrm{ml}$. this occurred more frequently. No bias appeared to be introduced by the omission of these slopes in calculating the means. Furthermore, the variation between replicate slopes in some assays was greater with higher concentrations of isoniazid $(12.8 \mu \mathrm{g} . / \mathrm{ml}$. and above) than with lower concentrations. The useful range of the method thus appears to be about 0.1 to $12.8 \mu \mathrm{g} . / \mathrm{ml}$.

\section{RESULTS}

RELATIONSHIP BETWEEN ZONE OF INHIBITION AND ISONIAZID CONCENTRATION The relationship between the zone of inhibition on the slopes after 10 days' incubation, and the concentration of isoniazid in serial two-fold dilutions in water is shown in Table I. The mean length of the zones increased from $17 \cdot 7 \mathrm{~mm}$. with $0 \cdot 1 \mu \mathrm{g}$. $/ \mathrm{ml}$. isoniazid to $66 \cdot 3 \mathrm{~mm}$. with $12.8 \mu \mathrm{g} . / \mathrm{ml}$. The analysis of variance indicates that the zones of inhibition were linearly related to $\log$ isoniazid concentration. Analyses of other similar experiments also indicated a satisfactory linear relationship. However, both the slope of the line and the mean size of the zones of inhibition varied from experiment to experiment, so that it is essential that a set of control solutions containing known concentrations of isoniazid be set up in each batch of assays.

As the period of incubation of the slopes was prolonged, the zones of inhibition became smaller. In the experiment shown in Table $I$, the zones at 14 days and at 21 days were, on average, smaller than the 10-day zones by $4.8 \mathrm{~mm}$. and $7.7 \mathrm{~mm}$., respectively.
TABLE I

RELATIONSHIP BETWEEN ZONE OF INHIBITION

AND ISONIAZID CONCENTRATION IN WATER

\begin{tabular}{clc}
\begin{tabular}{l} 
Isoniazid $\begin{array}{l}\text { Concentration } \\
(\mu g . / m l .)\end{array}$ \\
\cline { 2 - 3 }
\end{tabular} & Readings of Individual Slopes & Mean \\
\hline $0 \cdot 1$ & $16,20,19,20,16,15$ & $17 \cdot 7$ \\
$0 \cdot 2$ & $26,20,24,23,27,22$ & $23 \cdot 7$ \\
$0 \cdot 4$ & $31,31,34,30,31,35$ & $32 \cdot 0$ \\
$0 \cdot 8$ & $34,39,40,39,38,40$ & $38 \cdot 3$ \\
$1 \cdot 6$ & $45,47,39,48,49,44$ & $45 \cdot 3$ \\
$3 \cdot 2$ & $50,52,56,51,52,55$ & $52 \cdot 7$ \\
$6 \cdot 4$ & $56,62,64,61,66,57$ & $61 \cdot 0$ \\
$12 \cdot 8$ & $70,68,62,63,62,73$ & $66 \cdot 3$ \\
\multicolumn{4}{c}{ Degrees Mean } \\
ANALYSIS OF VARIANCE \\
Source of Variation \\
\multicolumn{4}{c}{ Freedom } \\
\hline
\end{tabular}

\begin{tabular}{lllll}
\hline Between isoniazid concentrations $^{1}$ & 7 & $1816.75 \quad 190.24$ & $<0.001$
\end{tabular}

Linear regression

Deviations from linearity

Between replicate slopes

$2700.481329 .89<0.001$

$2 \cdot 80$ - NS ${ }^{2}$

Between replicate slopes 40
${ }^{1}$ The isoniazid concentrations were expressed as logarithms

${ }^{2} \mathrm{NS}$ indicates that the variance ratio is less than 1.0 .

THE TEST STRAIN The influence of the age of the test culture on the zone of inhibition was examined by inoculating five-day, seven-day, 10-day, and 21-day cultures of the test strain each on to eight slopes and assaying solutions of $0 \cdot 2,0 \cdot 6,1 \cdot 8$, and $5.4 \mu \mathrm{g} . / \mathrm{ml}$. isoniazid in water on pairs of these slopes. No differences were found in the mean zones or in the slope of the line relating zone to log concentration between the five-, seven-, or 10-day cultures. The slopes inoculated with the 21-day culture had zones, on average, $3.7 \mathrm{~mm}$. longer and the slope of the line was slightly steeper than in the slopes inoculated with the younger cultures.

The dilution of the culture used for inoculating the slopes was studied in an experiment which was also designed to investigate the influence of the volume of the agar butt containing the material to be assayed (Table II). An undiluted nine-day culture of the test strain, a $1: 4$ dilution of this culture, and a 1:16 dilution were each inoculated on to 12 slopes with the felt spreader. Solutions of $0.2,0.6$, and $1.8 \mu \mathrm{g} . / \mathrm{ml}$. isoniazid in water were mixed with agar and added in volumes of $0.25,0.5$, $1 \cdot 0$, and $2.0 \mathrm{ml}$. to the base of the slopes. The mean zones of inhibition for the undiluted cultures were $27.75 \mathrm{~mm}$. for the undiluted culture, $30.33 \mathrm{~mm}$. for the $1: 4$ dilution, and $33.67 \mathrm{~mm}$. for the $1: 16$ dilution. Since the undiluted culture yielded small zones with $0.2 \mu \mathrm{g} . / \mathrm{ml}$. isoniazid and the edge of the zone of inhibition was difficult to read with the $1: 16$ dilution, the $1: 4$ dilution appeared to be the most satisfactory and was used in further work. It can be concluded that the age of the test culture is not critical. However, since the zone of inhibition is considerably 
TABLE II

EFFECT OF INOCULUM SIZE AND VOLUME OF AGAR BUTT ON THE ZONE OF INHIBITION

\begin{tabular}{|c|c|c|c|c|c|c|}
\hline \multirow{2}{*}{$\begin{array}{l}\text { Inoculum } \\
\text { (dilution of } \\
\text { 9-day culture) }\end{array}$} & \multirow{2}{*}{$\begin{array}{l}\text { Isoniazid } \\
\text { Concentration } \\
\text { in Agar Butt } \\
(\mu \mathrm{g} . / \mathrm{ml} .)\end{array}$} & \multicolumn{5}{|c|}{ Volume of Agar Solution in Butt $(\mathrm{ml})}$. \\
\hline & & 0.25 & $0 \cdot 5$ & $1 \cdot 0$ & $2 \cdot 0$ & Mean \\
\hline \multirow[t]{4}{*}{ Undiluted } & $0 \cdot 2$ & $2^{1}$ & 9 & 12 & 16 & $9 \cdot 75$ \\
\hline & 0.6 & 21 & 31 & 31 & 36 & $29 \cdot 75$ \\
\hline & $1 \cdot 8$ & 40 & 44 & 44 & 47 & $43 \cdot 75$ \\
\hline & Mean & $21 \cdot 0$ & $28 \cdot 0$ & $29 \cdot 0$ & 33.0 & $27 \cdot 75$ \\
\hline \multirow[t]{4}{*}{1 in 4} & $0 \cdot 2$ & 8 & 18 & 17 & 19 & 15.50 \\
\hline & 0.6 & 19 & 35 & 28 & 36 & $29 \cdot 50$ \\
\hline & $1 \cdot 8$ & 39 & 46 & 48 & 51 & 46.00 \\
\hline & Mean & $22 \cdot 0$ & $33 \cdot 0$ & $31 \cdot 0$ & $35 \cdot 3$ & $30 \cdot 33$ \\
\hline \multirow[t]{4}{*}{1 in 16} & $0 \cdot 2$ & 6 & 15 & 18 & 21 & $15 \cdot 00$ \\
\hline & 0.6 & 30 & 36 & 34 & 38 & $34 \cdot 50$ \\
\hline & $1 \cdot 8$ & 46 & 52 & 41 & 57 & $51 \cdot 50$ \\
\hline & Mean & $27 \cdot 3$ & $34 \cdot 3$ & $34 \cdot 3$ & $38 \cdot 7$ & $33 \cdot 67$ \\
\hline Overall & Mean & $23 \cdot 4$ & $31 \cdot 8$ & $31 \cdot 4$ & $35 \cdot 7$ & $30 \cdot 58$ \\
\hline
\end{tabular}

${ }^{1}$ Zone of inhibition in $\mathrm{mm}$.

influenced by the size of the inoculum, it is essential that control solutions be set up with each batch of assays.

VOLUME OF THE AGAR BUTT The volume of the agar solution in the butt of the slopes was also studied in the experiment illustrated in Table II. The mean zones of inhibition with volumes of $0.25,0.5,1.0$, and $2.0 \mathrm{ml}$. in the butts were $23.4,31.8,31 \cdot 4$, and $35.7 \mathrm{~mm}$. Thus, an increase in the volume of the butts resulted in larger zones of inhibition, particularly when the volumes were increased from 0.25 to $0.5 \mathrm{ml}$. A volume of $0.5 \mathrm{ml}$. was chosen for further work to avoid undue sensitivity to variation in butt volume and as the best compromise between the need for economy in the serum to be assayed and for large zones of inhibition with low concentrations of isoniazid.

RECOVERY OF ISONIAZID FROM SERUM In several experiments known concentrations of isoniazid in serum were assayed against known concentrations in water. These results are summarized in Table III, which gives the number of slopes used in the assays on solutions in water and in serum as an indication of the accuracy of the estimate, the number of subjects whose serum were used in each experiment, and the mean concentration of isoniazid found in the serum by assay against water controls, expressed as a percentage of the true concentration of isoniazid added to the serum. For example, in experiment 1, concentrations of isoniazid ranging in serial twofold steps from $0.2 \mu \mathrm{g}$. $/ \mathrm{ml}$. to $25.6 \mu \mathrm{g}$. $/ \mathrm{ml}$. were made up in water and horse serum. Each of the 16 solutions was assayed on three slopes. The mean concentration of isoniazid in the sera as estimated from the water assays was $58 \%$ of the concentrations actually added. The slopes of the lines relating zone of inhibition to $\log$ isoniazid concentration were $\stackrel{0}{9}$ similar for the water and serum solutions. In experiment 3 a single specimen of human serum con- 음 taining $1.6 \mu \mathrm{g} . / \mathrm{ml}$. was assayed against five solutions $\frac{\omega}{\vec{T}}$ in water ranging by two-fold steps from 0.3 to $3.2 \AA$ $\mu \mathrm{g} . / \mathrm{ml}$. The recovery from serum as estimated from $\nRightarrow$ the water controls was $83 \%$ of the concentration $\overrightarrow{0}$ added.

In horse serum the concentration estimated from $\overrightarrow{\vec{\omega}}$ the water control ranged from $54 \%$ to $74 \%$ of the actual concentration added. The corresponding? recovery from human serum ranged from $70 \%$ to $\vec{V}$ $100 \%$. These findings suggest that the recovery from $\sigma$ human serum may be greater than from horse serum. The preparation of horse serum control for the $N$ assay of isoniazid in human serum would therefore 음 be undesirable. If water controls are used, the concentration estimated in human serum can be $z$ corrected, if required, for a recovery rate of $75 \% \AA$ by multiplying the estimate by $1 \cdot 33$.

In experiment 8 (Table III) isoniazid was added to sera from eight subjects in concentrations of $\vec{\theta}$ $0.4 \mu \mathrm{g} . / \mathrm{ml}$. and $3.2 \mu \mathrm{g} . / \mathrm{ml}$., each concentration in each serum being assayed in four slopes. At the ${ }^{\mp}$ same time, solutions in water containing the same two concentrations of isoniazid were each assayed on 12 slopes. The recoveries from the eight serao were $59 \%, 71 \%, 72 \%, 75 \%, 75 \%, 78 \%$, and $79 \%, \%$ respectively. The variation between the recoveryo rates from the individual sera was significant $\overrightarrow{\vec{O}}$ $(P=0.01)$. The existence of variation in the recovery 3 from different human sera will therefore increase the? error of the method unless control solutions can be made up in drug-free serum from the patient whose serum is to be assayed (a procedure that is only? possible in exceptional circumstances).

TABLE III

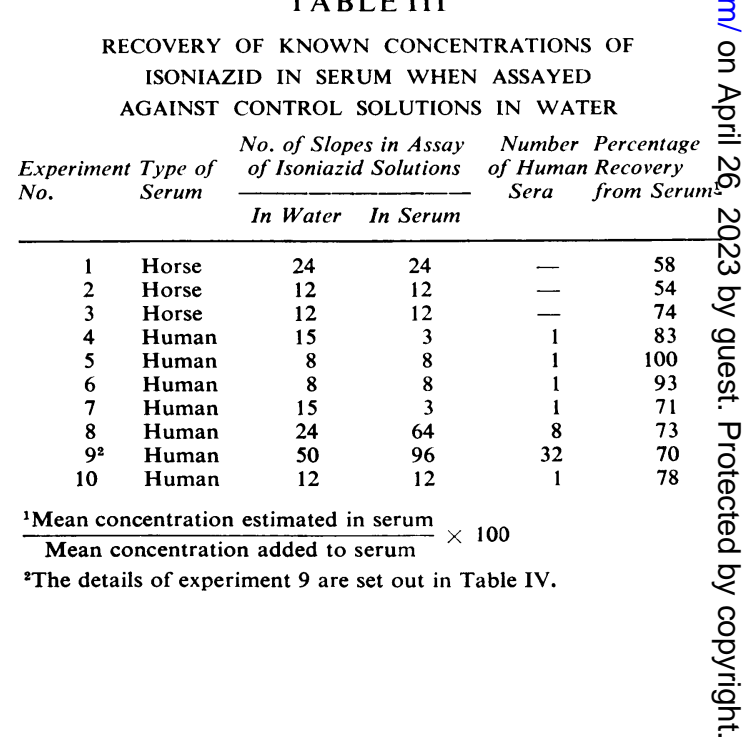


Haemolysis in serum did not appear to affect the assay, since the addition of $5 \%$ human red cells lysed by freezing and thawing to human serum did not alter the zones of inhibition. The zones produced by isoniazid in oxalated or heparinized blood were, however, smaller than the zones produced by the same concentration in serum.

ACCURACY OF THE ASSAY Isoniazid was added to 32 human sera in known randomly chosen concentrations within the range 0.2 to $3.2 \mu \mathrm{g}$. $/ \mathrm{ml}$. The sera were then assayed in five batches of tests with one set of water controls containing 0.2 and $3 \cdot 2$ $\mu \mathrm{g} . / \mathrm{ml}$. isoniazid in each batch; three slopes were used for each serum and five slopes for each of the water controls. In Table IV are set out the concentrations of isoniazid added to the serum, the concentrations estimated from the assay by reference to the water control, and the estimated concentrations corrected for the low recovery from serum by multiplying by 1.431 (a correction which equalizes the geometric means of the known and the estimated

\section{TABLE IV}

RESULTS OF ASSAY OF HUMAN SERA CONTAINING KNOWN CONCENTRATIONS OF ISONIAZID

\begin{tabular}{|c|c|c|c|}
\hline \multirow{2}{*}{$\begin{array}{l}\text { Batch } \\
\text { No. }\end{array}$} & \multicolumn{3}{|c|}{ Isoniazid Concentration $(\mu \mathrm{g} . / \mathrm{ml})}$. \\
\hline & $\begin{array}{l}\text { Added to } \\
\text { Serum }\end{array}$ & $\begin{array}{l}\text { Estimated } \\
\text { from Water } \\
\text { Controls }\end{array}$ & $\begin{array}{l}\text { Corrected } \\
\text { Estimates }^{1}\end{array}$ \\
\hline \multirow[t]{5}{*}{1} & 0.43 & 0.31 & 0.44 \\
\hline & $1 \cdot 88$ & $1 \cdot 32$ & 1.89 \\
\hline & 0.33 & 0.22 & 0.32 \\
\hline & 0.54 & 0.35 & 0.51 \\
\hline & 0.39 & 0.25 & 0.36 \\
\hline \multirow[t]{5}{*}{2} & $2 \cdot 04$ & 1.80 & $2 \cdot 58$ \\
\hline & 0.22 & $0 \cdot 18$ & 0.26 \\
\hline & $1 \cdot \overline{75}$ & $1 \cdot 50$ & $2 \cdot 15$ \\
\hline & $1 \cdot 32$ & 1.88 & $2 \cdot 69$ \\
\hline & 0.86 & 0.88 & $1 \cdot 26$ \\
\hline \multirow[t]{5}{*}{3} & $1 \cdot 27$ & $1 \cdot 70$ & $2 \cdot 43$ \\
\hline & 1.49 & 1.87 & $2 \cdot 68$ \\
\hline & 0.25 & $0 \cdot 13$ & $0 \cdot 19$ \\
\hline & 0.41 & 0.39 & 0.56 \\
\hline & 1.90 & $2 \cdot 45$ & $3 \cdot 51$ \\
\hline \multirow[t]{5}{*}{4} & $1 \cdot 08$ & 0.61 & 0.81 \\
\hline & $1 \cdot 55$ & 0.89 & $1 \cdot 27$ \\
\hline & $2 \cdot 31$ & 1.93 & $2 \cdot 76$ \\
\hline & 0.86 & 0.46 & 0.66 \\
\hline & 1.93 & $1 \cdot 15$ & 1.65 \\
\hline \multirow[t]{12}{*}{5} & 3.05 & 1.67 & $2 \cdot 39$ \\
\hline & 0.38 & 0.16 & 0.22 \\
\hline & 0.51 & 0.24 & 0.34 \\
\hline & 0.32 & 0.24 & 0.34 \\
\hline & 0.94 & 0.20 & 0.28 \\
\hline & 0.38 & 0.32 & 0.46 \\
\hline & 0.20 & $0 \cdot 16$ & 0.24 \\
\hline & 1.85 & 1.04 & 1.49 \\
\hline & 1.45 & 0.57 & 0.82 \\
\hline & 1.42 & 0.73 & 1.04 \\
\hline & 0.60 & 0.52 & 0.74 \\
\hline & 0.71 & 0.60 & 0.86 \\
\hline
\end{tabular}

${ }^{1}$ Estimated concentration multiplied by 1.431 , the antilogarithm of the difference between the means of the logarithms of the known and estimated concentrations. concentrations). In calculating the error of the method the known concentrations and the corrected estimate were converted to logarithms. The standard deviation of the difference between the known concentration and the corrected estimate was $\pm 0.169 \log _{10} \mu \mathrm{g} . / \mathrm{ml}$.; in terms of $\mu \mathrm{g} . / \mathrm{ml}$. the standard deviation was therefore $+47 \%$ and $-32 \%$.

STABILITY OF ISONIAZID IN SERUM Aliquots of human serum to which had been added $6.4 \mu \mathrm{g} . / \mathrm{ml}$. isoniazid were stored at $37^{\circ} \mathrm{C}$, $22^{\circ} \mathrm{C}$., $0^{\circ} \mathrm{C}$., and $-20^{\circ} \mathrm{C}$. At intervals during the next 28 days the isoniazid content was assayed. No appreciable change in concentration occurred during three days at $37^{\circ} \mathrm{C}$., seven days at $22^{\circ} \mathrm{C}$., and 28 days at $0^{\circ} \mathrm{C}$. or at $-20^{\circ} \mathrm{C}$. Approximately $70 \%$ loss of activity had occurred at seven days in serum stored at $37^{\circ} \mathrm{C}$. and at 28 days in serum stored at $22^{\circ} \mathrm{C}$.

\section{DISCUSSION}

The diffusion method of microbiological assay described is convenient and rapid to perform. For the past four years successive groups of students have all obtained reasonable results when using it for the first time, so that it also appears to be a robust method. The accuracy of the assay is not as high as can be obtained in diffusion systems for measuring other substances. For example, Mitchison, Holt, and Moore (1949) assayed sera containing known concentrations of streptomycin using a method in which the streptomycin diffused through tubes containing agar pre-seeded with Staph. pyogenes. The standard deviation of the differences between the estimated and known concentrations of streptomycin was, in logarithmic units, \pm 0.066 , which is lower than the corresponding estimates of $\pm \mathbf{0 . 1 6 9}$ for the isoniazid assays. Nevertheless, the isoniazid assay method is sufficiently accurate for most purposes. More accurate results could be obtained by increasing the number of replicate slopes used for the test serum and for each of the controls, but the variation in recovery rates from serum to serum would limit the improvement that could be achieved in this manner.

In any microbiological assay of isoniazid, tubercle bacilli must be used as the test organism, since no other bacteria are sufficiently sensitive to the drug. The results of the assay can therefore only be obtained several days after it has been set up. Chemical methods for measuring isoniazid in serum give a rapid result, but those available either cannot measure low concentrations (Maher, Whitney, Chambers, and Stanonis, 1957) or require expensive equipment (Peters, 1960).

When isoniazid in human serum was assayed 
against water controls, the estimated concentrations were about 70 to $80 \%$ of the concentrations actually added to the serum. The reasons for this low recovery are obscure. It does not appear to be due to binding of isoniazid by serum proteins (Claunch, Castro, and Barnes, 1963). There would seem to be no necessity to correct for the low recovery if comparisons are made between results on different sera assayed by the method. However, if comparisons are to be made with estimates obtained by other methods, a correction would be required.

Isoniazid can be assayed in serum containing streptomycin, since the test strain is resistant to this antibiotic. If $p$-aminosalicylic acid (P.A.S.) is present, large zones of inhibition are produced and, indeed, the diffusion system is quite satisfactory for the microbiological assay of $p$-aminosalicylic acid. Grosset and Canetti (1960) have shown that the addition of $500 \mu \mathrm{g} . / \mathrm{ml}$. p-aminobenzoic acid (P.A.B.A.) to the serum will antagonize the activity of any concentration of P.A.S. likely to be present in the serum. Addition of $3,000 \mu \mathrm{g} . / \mathrm{ml}$. P.A.B.A. to the $4 \%$ agar mixed with the serum will thus allow the estimation of isoniazid in the presence of P.A.S.O

\section{REFERENCES}

Claunch, B. C., Castro, V., and Barnes, W. T. (1963). Transactions of the 22nd Research Conference in Pulmonary Diseases, p. 37. ڤ్ Veterans Administration, Washington.

Cohn, M. L., Middlebrook, G., and Russell, W. F., Jr. (1959). J. clin. $\vec{\circ}$ Invest., 38, 1349 .

Dufour, A. P., Knight, R. A., and Harris, H. W. (1963). Transactions of the 22nd Research Conference in Pulmonary Diseases, p. 57. Veterans Administration, Washington.

Grosset, J. and Canetti, G. (1958). Rev. Tuberc. (Paris), 22, 1077.

,,-- (1960). Ibid., 24, 633.

Jensen, K. A. (1955). Bull. int. Un. Tuberc., 25, 89. (1957). Amer. Rev. Tuberc., 76, 852.

Mitchison, D. A., Holt, H. D. and Moore, S. H. (1949). J. clin. Path. N 2, 213.

Peters, J. H. (1960). Amer Rev. resp. Dis., 81, 485.

Schmidt, L. H. (1962). Ibid., 86, 561.

Schmiedel, A. (1954). Beitr. Klin. Tuberk., 112, 475.

, (1958a). Z. Tuberk., 112, 48.

-, (1958b). Beitr. Klin. Tuberk., 119, 206.

Sunahara, S., Urano, M., Lin. H, T., Cheg., R. J., and Jarumilinda A. (1963). Acta tuberc. scand.. 43, 181. 